\title{
124
}

UDC: $332.832 .5(680)$

DOI: 10.5379/urbani-izziv-en-2013-24-02-004

Received: 1 February 2013

Accepted: 18 March 2013

Nico KOTZE

\section{A community in trouble? The impact of gentrification on the Bo-Kaap, Cape Town}

The Bo-Kaap is an older inner-city, working-class neighbourhood in Cape Town, South Africa. By the 1930s, the area had degenerated into an overcrowded and run-down neighbourhood, consisting largely of dilapidated houses, but by 1941 about 150 housing units had been expropriated by the local authority for redevelopment in a comprehensive renewal scheme for the area. However, the process was halted with the formation of the so-called "Group for the Preservation of the Malay Quarter", which fought against the demolition of the houses. At present, the area with its colourful housing units and 11 mosques is part of Cape Town's cultural heritage and a very im- portant tourist attraction. As in the case of De Waterkant, a gentrified neighbourhood adjacent to it, the area has seen a large number of housing units renovated and upgraded. Property prices have increased dramatically, although they are still relatively low, while the number of properties sold is also on the rise - so much so that the community leaders and especially the Muslim residents are in a constant battle to preserve the neighbourhood's cultural identity.

Key words: gentrification, identity, Cape Town, property prices, conservation, community 


\section{Introduction}

The Bo-Kaap, one of the older neighbourhoods of Cape Town, and adjacent to the central business district (CBD) of the city, can trace its history back to the late eighteenth century, when modest housing for tenants was developed in this area. This was due to a shortage of accommodation and housing units for the working class as a result of the emancipation of the slaves and large-scale immigration from Europe to the Cape. By the early twentieth century, the Bo-Kaap had deteriorated into a run-down, slum-like neighbourhood. As early as 1946, there were attempts by a group of interested volunteers and the city council to halt the process of decay by identifying seventeen housing units for restoration. Although the urban renewal process in this area was institutionalised and urban-policy driven, it could be seen to be laying the foundation for what could surely be associated with gentrification in this neighbourhood - as evidenced in the changes in the housing stock and population. This process had started to manifest itself in Cape Town, on a very small scale, even before Ruth Glass (1964) coined the term "gentrification" in the early 1960s, observing that the working class quarters of London were being invaded by the middle classes - upper and lower. Shabby modest mews and cottages were being taken over when their leases expired, and were becoming elegant, expensive residences.

As gentrification became a more visible phenomenon in cities all over the world during the late 1980s, it was featured as the central issue in a vast number of urban studies and discussions (Franzén, 2005). In the past, gentrification was generally referred to as the invasion of working-class neighbourhoods in the inner city by people of the middle class, with a higher income, resulting in the displacement or replacement of many of the original occupants. Gentrification involves the renovation of dilapidated housing stock to meet the requirements of the new owners (Kotze \& Van der Merwe, 2000; see also Smith \& Williams, 1986; Bourne, 1993). Furthermore, it is claimed that this process creates inflated rental and property prices in these neighbourhoods, resulting in the displacement of the original low-income earners or unemployed inhabitants over time and the influx of a middle-class group, which could alter the social character of the area and the cost of service delivery to satisfy the expectations of the higher income group (Beauregard, 1986; Hamnett, 1991; Cameron, 1992; Atkinson, 2000). However, it appears that this concept refers to a much more complex urban process and is therefore difficult to explain. Gentrification has evoked some intense discussions, with some researchers arguing in support of maintaining the initial "Ruth Glass" definition, whereas a seemingly increasing group is in favour of a broader-based understanding of the process (Lees et al., 2008; Visser \& Kotze, 2008). Furthermore, "early attempts to analyse the process tended to stress the role of in- dividual gentrifiers and real estate developers and to pay little attention to the role of the state" (Murphy, 2008: 2522).

Three interrelated processes can be identified to explain why gentrification has become more widespread and better understood on a wider front. The first is that gentrification has been interpreted as the creation of a sophisticated lifestyle practised by specific elements of the global capitalist classes (Rofe, 2003). The second process is that gentrification has spilled over into new areas through new global influences. Rowland Atkinson and Gary Bridge (2005) claim that it appears that gentrification has transferred outwards from large cities of North America, western Europe and Australia to other regions of the globe. Third, "gentrification has been understood as an important part of neo-liberalism" (Harris, 2008: 2409). According to Neil Smith (2002: 440), gentrification had "advanced by the 1990s into a vital urban approach for the urban development process by city governments in association with private capital in cities around the world". These efforts, to provide an explanation for the global spread of gentrification and the trend itself, have been to treat the process within the context of cosmopolitanism or neo-liberalism (Harris, 2008). According to Andrew Harris (2008: 2409), this has been "in part the product of researchers in this field failing to engage fully with work outside their own sub-discipline". This idea is reiterated by Tim Butler \& Loretta Lees (2006), who state that literature on globalisation and gentrification has paid little attention to the work of alternative fields of interest.

According to Darren Smith (2008), there is an established interest in the connection between gentrification and urban policy that tends to concentrate on two sets of research questions. The first focuses on policies to deepen knowledge of the origins and causes of gentrification. The emphasis is on clarifying the connection between the temporality of gentrification and contradictions in policies by urban managements, but with the focus being directed at reinforcing the economic restructuring of the urban landscape and housing market and the re-creation of a socially new class in these areas (Smith, 1979; Ley, 1994). Secondly, according to Stuart Cameron (2003), scholars also examine the costs and benefits of gentrification, attempting to disentangle the particular groups that profit from or suffer as a result of the process of gentrification. As Atkinson (2004: 107) asks: "Does gentrification help or harm residential neighbourhoods?" However, "what is required is a nuanced appreciation of how the diverse influences of gentrification are interlocked and entrenched within gentrified areas and how this touches and influences the quality of life and welfare of different social groups, both in the sense of material and non-material outcomes" (Smith, 2008: 2543).

As academics deliberate on whether or not gentrification leads to the displacement of the working classes and to segregation 
and social polarisation within cities, the process is being progressively supported in policymaking circles, the members of which believe that it leads to more sustainable urban communities that reflect a greater degree of social mixing, are less segregated and contribute to more acceptable living conditions (Lees, 2008). Furthermore, as Nicolas Blomley (2004) stated, renewal programmes often seek to promote home ownership, in the belief that this encourages independence, entrepreneurship and community pride. On this account, gentrification is to be encouraged, in that it entails the replacement of communities of non-property-owning, transitory and problematic populations with an active, responsible population of homeowners set on improving the neighbourhood.

This paper investigates the housing unit changes that have taken place in the inner-city suburb of the Bo-Kaap and sets out to establish the impact on its population. It aims at unravelling the changes, as well as analysing the different and diverse influences that have played a role in this historical neighbourhood of Cape Town to change the former slum area into one of the most sought-after neighbourhoods in the city. A close analysis of the $\mathrm{CBD}$ and the surrounding inner-city neighbourhoods of Cape Town made it evident that gentrification has played a major role in the redevelopment of the inner city in general and the study area in particular. This paper does not set out to prove that gentrification is taking place in the Bo-Kaap, but rather presents a narrative on the Bo-Kaap population and their history, analysing the impact of political processes and the changing environment on the cultural and social fabric of the study area inhabitants. However, this study is different from all others in that it examines the historical development of the study area and how gentrification - that is, the housing unit upgrade and the resulting property price increases - has had an impact on the social fabric of the population that can result in the displacement of the traditional neighbourhood inhabitants.

Data on the socioeconomic attributes of the Bo-Kaap inhabitants were extracted from the 1996, 2001 and 2011 censuses. A second source of data was Municipality of Cape Town records, which provided information on the number and size of properties sold, the selling prices and the addresses within or outside the study area to which the initial municipal bills were mailed. An additional source of information was the Cape Town Deeds Office, where title deeds reflecting the ownership and mortgages (known as "bonds" in South Africa) on all properties are registered. The information from the Municipality and the Deeds Office was used to ascertain whether outsiders were moving into the area. To gauge the attitude towards change in the neighbourhood, interviews were conducted with willing interviewees on a community market day, and also with community leaders and religious leaders.

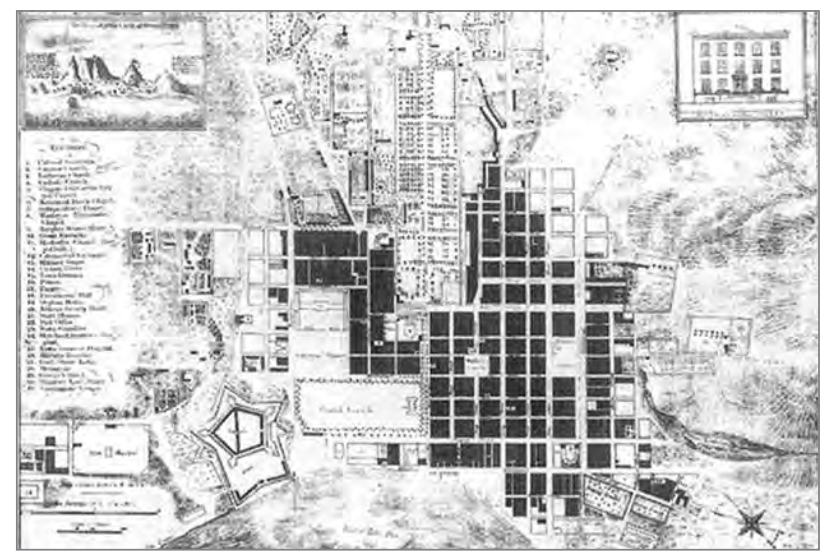

Figure 1: The 1827 plan of Cape Town by Thompson. The streets of the Bo-Kaap are more or less established to the right of the town plan (source: Todesini \& Japha, 2003).

This paper is divided into five sections. The first section briefly outlines the development and conservation of this historic neighbourhood. The second looks at the creation of a racial identity that could have been applied to the area during the Apartheid era. The third section gives an overview of the present-day inhabitants and the urban identity of the population in the Bo-Kaap. The fourth section looks at current property market aspects of the area. The final section ends with a few concluding remarks.

\section{The development and conservation of the Bo-Kaap}

The residential area of the Bo-Kaap, on the fringe of the CBD of Cape Town, was established during the last two decades of the eighteenth century and developed over the subsequent 150 years (Todeshini \& Japha, 2003). Clearly distinguishable on the 1786 plan of Cape Town by Van der Graaf, Barbier and Tribault is the development of the street patterns of the city up to Buitengracht Street, with no indication of any development of what is now known as the Bo-Kaap. The development of the two parallel streets in this neighbourhood, namely Rose and Chippinni, was featured for the first time on Thompson's plan, dating back to 1827 (Figure 1). By 1862, Snow's plan showed that the layout and street pattern of the Bo-Kaap had been established. The spatial development of this area was a response to increasing immigration, the emancipation of the slaves and a demand for housing with moderate rental rates for the growing population (Wilkinson \& Kragolsen-Kille, 2006).

By the 1930s, the Bo-Kaap had developed into an overcrowded and rundown neighbourhood, in close proximity to the CBD of Cape Town. During this period, there had been persistent complaints in Cape Town's press about slums, with much of the attention being directed towards the inner-city areas of 


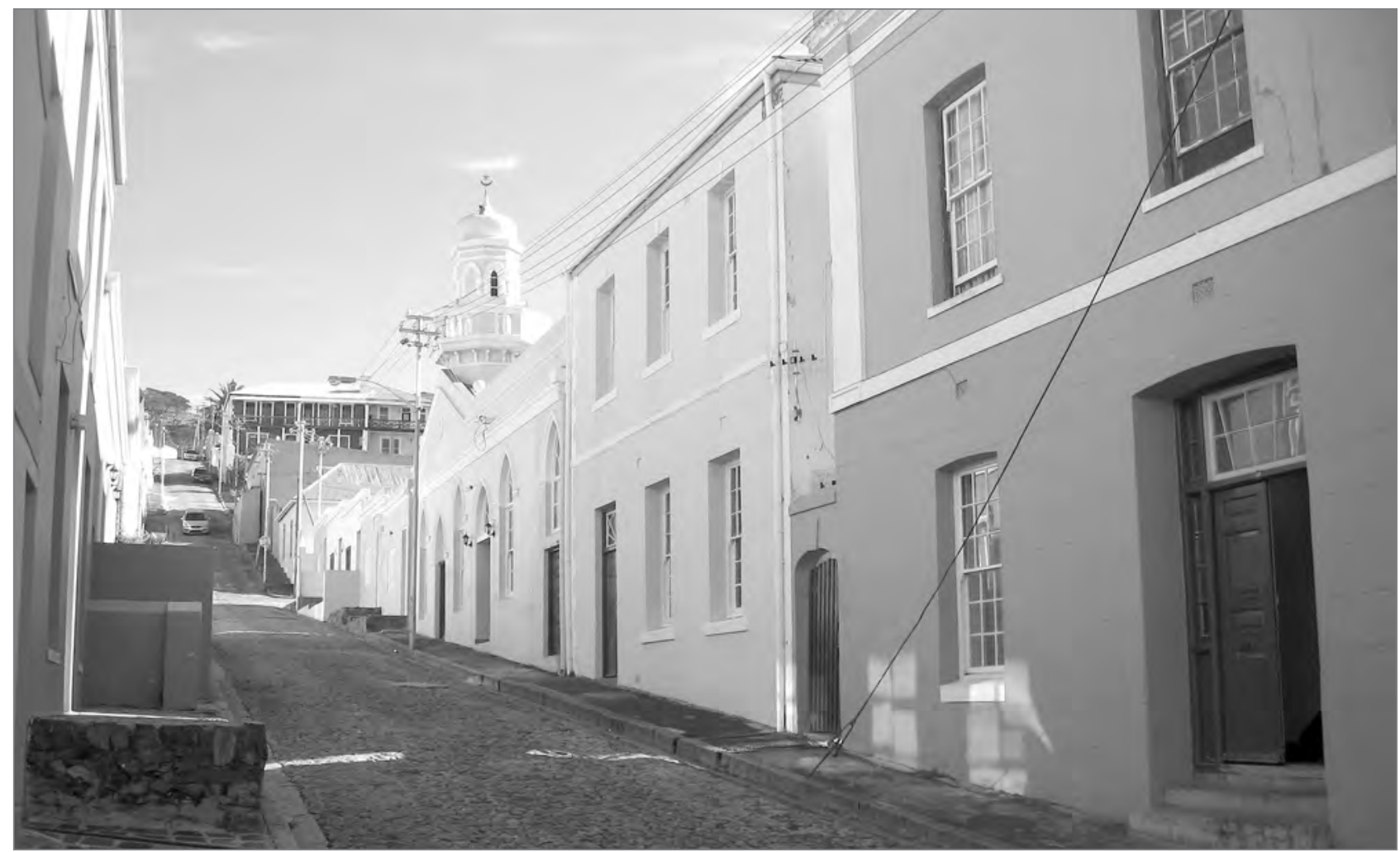

Figure 2: A street scene in Bo-Kaap with one of the eleven mosques clearly visible (photo: Nico Kotze).

Jerry Street Ward, District Six and the Bo-Kaap. A mechanism to involve local governments in urban slum areas was put in place when the Slum Act of 1934 was passed by the national government. It granted extensive powers to local authorities to intervene in the slum neighbourhoods under their jurisdiction (Todesini \& Japha, 2003). By 1941, about 150 houses in the Bo-Kaap, mostly dating from the eighteenth and nineteenth centuries, had been expropriated by the local authority for redevelopment in a large renewal scheme for the area (Wilkinson \& Kragolsen-Kille, 2006).

The demolition of the Bo-Kaap neighbourhood seemed inevitable by 1943 . However, the process was halted and controls were put in place to prevent any demolition by the so-called "Group for the Preservation of the Malay Quarter", headed by Dr Jansen, I. D. du Plessis (the academic and author) and other prominent citizens of Cape Town (Todesini \& Japha, 2003). The group lobbied for the involvement of the Historical Monuments Commission (HMC), which immediately affiliated itself with the objective of preserving the so-called "Old Malay architecture" (Cape Archives, 3/CT 4/2/1/1/720). A block of seventeen housing units was identified in 1946 by the group and the City of Cape Town for preservation and restoration. Figure 2 presents a typical street scene, with one of the mosques on the right-hand side of the street. The project was completed in 1950, but the costs incurred exceeded the allocated budget. This led to a decade of tension, with the city council wanting to redevelop the area, but with the balance of power being such that neither of the parties could succeed because the council could not redevelop the area without the cooperation of the HMC (Todesini \& Japha, 2003).

Crucial in backing up the preservation of the Bo-Kaap was the assumption of power by the Nationalist Party in 1948, which placed ethnic identity on the national agenda and which resulted in the development of the politically-segregated Apartheid cities of South Africa. In 1951, Du Plessis was appointed Commissioner of Coloured Affairs. He was placed in the enviable position of advancing his stance on the "Malay" issue and of declaring the area a "Malay Group Area" (Wilkinson \& Kragolsen-Kille, 2006). This milestone was reached in 1957, and from 1962 onwards no other population group, apart from the designated Malays, could own property in the Bo-Kaap (Todesini \& Japha, 2003). In 1961, the Department of Community Development was established to coordinate the implementation of the Group Areas Act. This department, as well as the Department of Coloured Affairs, fell under P. W. Botha, with Du Plessis now promoted to the position of full secretary. The first action Du Plessis undertook was to recommend that the entire area of the Bo-Kaap be proclaimed a national monument. During this period it was decided to preserve the facades of the houses in the area, while more modern houses were constructed behind the facades (Todesini \& Japha, 2003). 


\section{The "Malaying" of the Bo-Kaap community}

According to Robyn Wilkinson and Astrid Kragolsen-Kille (2006), the term "Malay" in a South African context has its roots in slavery and has no ethnic significance. Only about one per cent of the 63,000 slaves that were brought to the Cape were from Malaysia, the bulk of the slaves coming from India, Africa, the island of Madagascar and southeast Asia. Furthermore, during the founding years of Cape Town, the population in the Cape was diversified, initially able to communicate by way of Melayu and Malayo-Portuguese, the trading languages of the Indian Ocean basin. However, after 1770, these languages were replaced by Dutch, which eventually evolved into Afrikaans (Davids, 1990).

A second part of the puzzle of creating the so-called "Malay" identity was when Islam was introduced to the Cape with the labourers from the Moluccas and political prisoners from Indonesia. However, the religion only really took root in the early 1800s, when Indian Muslim slaves from Bengal, the Malabar Coast and the interior of India were brought to the Cape. The term "Malay" was used during the nineteenth century to refer to the coloured Muslim population of all origins (Todesini \& Japha, 2003). This became a self-descriptive term during the first half of the twentieth century, especially during the Apartheid Era, when many Afrikaans-speaking Muslims took on the name in the hope that they would be accepted by the white elite because any form of association with black identity could lead to disadvantage in the context of oppression and racism within the country (Jeppe, 1986).

According to Achmat Davids (1990), up until the late 1920s the Bo-Kaap was a racially mixed neighbourhood for the poor of all races, and the numerous mosques in the area were established by the local Muslim community, which was split up into different groupings as numbers of Muslims in the Cape grew. A clear indication of the diversity of the population is reflected in the survey carried out by the Medical Officer of Health in 1946, where it was found that $40 \%$ of the inhabitants were "Malay" (Muslim people of colour), 31\% African, 27\% were "Cape Coloureds" (being Christians) and the balance were Indian (Cape Archives, 3/CT 4/2/1/1/720 20/6/46).

From the time that $\mathrm{Du}$ Plessis started to champion the cause of the Malay Quarter, he never once blamed the supposed social problems of the Bo-Kaap on poverty, but on the presence of outsiders (i.e., the Africans) in the neighbourhood (Du Plessis \& Lückoff, 1953). For Du Plessis, the motivation to ensure that this neighbourhood would be preserved was not only to "maintain the 'Malay' architecture, but also the reconstruction of the now diluted 'Malay' community in an ethnically
Table 1: Changes in the population of the Bo-Kaap according to 1996, 2001, 2011 censuses.

\begin{tabular}{|c|c|c|c|}
\hline Variables & $1996(\%)$ & $2001(\%)$ & $2011(\%)$ \\
\hline \multicolumn{4}{|l|}{ Ethnicity } \\
\hline Coloured & 79.0 & 73.1 & 95.2 \\
\hline White & 2.7 & 6.6 & 0.3 \\
\hline Indian & 3.8 & 6.1 & 3.2 \\
\hline Black & 2.6 & 14.1 & 1.3 \\
\hline Unspecified & 11.9 & & \\
\hline \multicolumn{4}{|l|}{ Religion } \\
\hline Islam & & & 56.9 \\
\hline Christian & & & 4.9 \\
\hline Other & & & 38.2 \\
\hline \multicolumn{4}{|l|}{ Age } \\
\hline$\leq 17$ years & * & 28.4 & 33.3 \\
\hline $18-54$ years & $*$ & 53.8 & 49.9 \\
\hline$>55$ years & 15.3 & 17.7 & 16.7 \\
\hline \multicolumn{4}{|l|}{ Language } \\
\hline English & 72.4 & 75.3 & 58.5 \\
\hline Afrikaans & 25.0 & 22.6 & 38.7 \\
\hline English/Afrikaans & & & 1.9 \\
\hline African/Other & 1.6 & 2.1 & 0.9 \\
\hline \multicolumn{4}{|c|}{$\begin{array}{l}\text { Education levels as attained } \\
\text { by those older than } 15\end{array}$} \\
\hline Up to grade 11 & 62.6 & 52.2 & \\
\hline Grade 12 & 21.9 & 25.3 & \\
\hline A tertiary degree & 15.4 & 22.6 & \\
\hline \multicolumn{4}{|l|}{ Work status } \\
\hline Employed & 50.9 & 50.6 & \\
\hline Unemployed & 49.1 & 49.4 & \\
\hline
\end{tabular}

Note: $\left(^{*}\right)$ Age categories did not correspond

Source: Statistics South Africa (1996, 2001, 2011)

pure neighbourhood" (Todesini \& Japha, 2003: 197). In his attempts to promote his ideals, Du Plessis also pointed out to the Apartheid government that to accommodate the "Malays" outside the Malay Quarter was to totally deny the goals of upholding the pride and happiness of the different racial groups - as envisaged by the Group Areas Act (Todesini \& Japha, 2003). Owing to his efforts, the neighbourhood was preserved, whereas areas such as District Six were razed to the ground and the communities relocated to Mitchell's Plain and other non-white neighbourhoods in Cape Town.

\section{The present day Bo-Kaap community}

In the study by Nico Kotze and Izak Van der Merwe (2000) to ascertain whether the urban renewal taking place could be classified as gentrification in Cape Town, the authors developed 
a profile of a typical gentrifier through discriminant analysis. However, very little evidence could be found to the effect that the average inhabitant of the Bo-Kaap corresponded with that of the average gentrification profile established for Cape Town.

At present, though, a very vocal part of the population (activists, community leaders and religious groups) of the Bo-Kaap is striving to retain their "Cape Malay" identity. This is not dissimilar to the case of the population of Santiago, Chile, where there is the "tendency for social groups to concentrate in certain areas of the city, creating areas and neighbourhoods that are socially homogeneous" (Márquez \& Pérez, 2008 cited in Márquez; 2011: 88). However, as is evident from the 1996, 2001 and 2011 census data, over time reference has been made to a separate ethnic group named "Cape Malay" (Table 1). Thus the question arises as to whether this term was not another racially motivated manipulation by the Apartheid government of the past. What is obvious is that at present the area is almost totally populated by the Coloured ethnic group (95\%). During the 1996 census, almost 12\% of the inhabitants did not specify their race, but this has changed since then. One can only speculate on the reasons for this: one possibility is that the inhabitants tried to retain their "Cape Malay" identity during the 1996 census; second, that it is more "fashionable" and to one's advantage to be a person of colour in the new political arrangement in South Africa. What is very surprising, according to the 2011 census, is the decline in the number of people from other racial groups in the Bo-Kaap.

According to the 2011 census, the majority of the inhabitants still record their religion as Islam (see Table 1). The age categories of the population in the study area have not changed much. This is in contrast to other gentrified areas of the world (Fillion, 1991; Lees, 1994), into which younger cohorts have moved. What is surprising, however, is the recorded change in the language of the inhabitants in the 2011 census showing a decrease in the number of English-speaking members of the population and an increase in the number of Afrikaans-speaking people. Perhaps it could be an indication of changing attitudes in South Africa and that people are more open and not ashamed to acknowledge that they are Afrikaans-speaking, a language that is very closely associated to the Nationalist Party and the Apartheid heritage of the country. Unfortunately, the same categories of educational levels and work status were not used in the 2011 census: comparisons of the 1996 and 2001 data, for example, reveal that higher qualifications were recorded for the residents in the study, but this was not the case with employment (see Table 1) An examination of the census data from 1996 to 2011 reveals that the socioeconomic attributes of the inhabitants of the Bo-Kaap have apparently not changed that dramatically. This is in line with the study by Ronnie Donaldson et al. (2013),

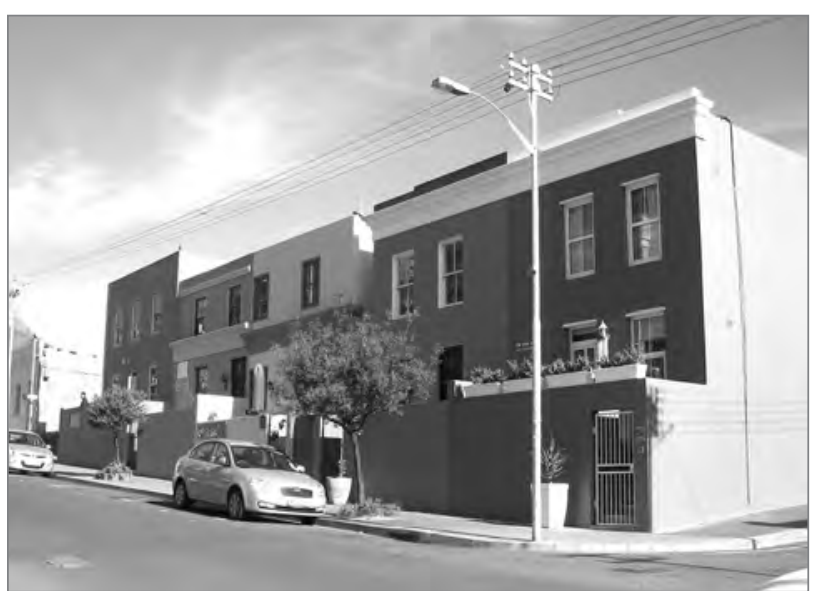

Figure 3: Redeveloped houses in the Bo-Kaap with the façades the same as the original houses (photo: Nico Kotze).

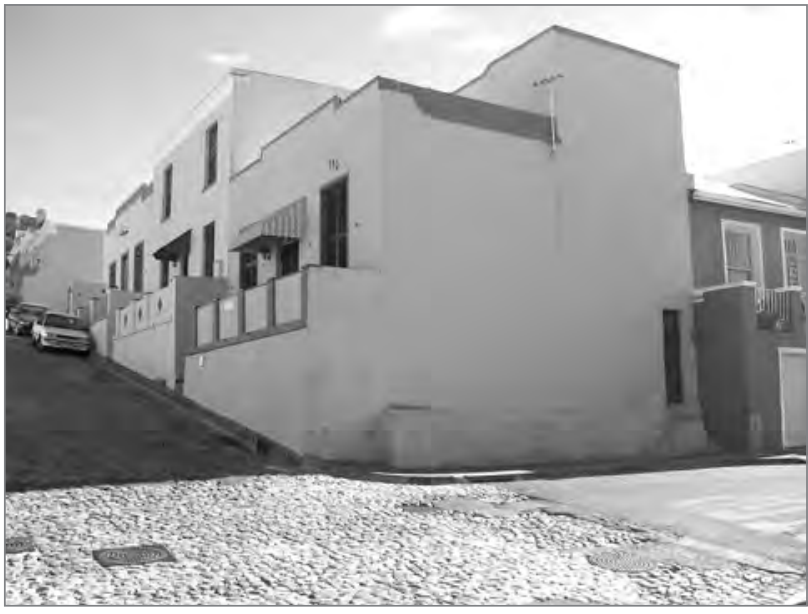

Figure 4: The cheapest housing unit sold in the Bo-Kaap during 2011 (photo: Nico Kotze).

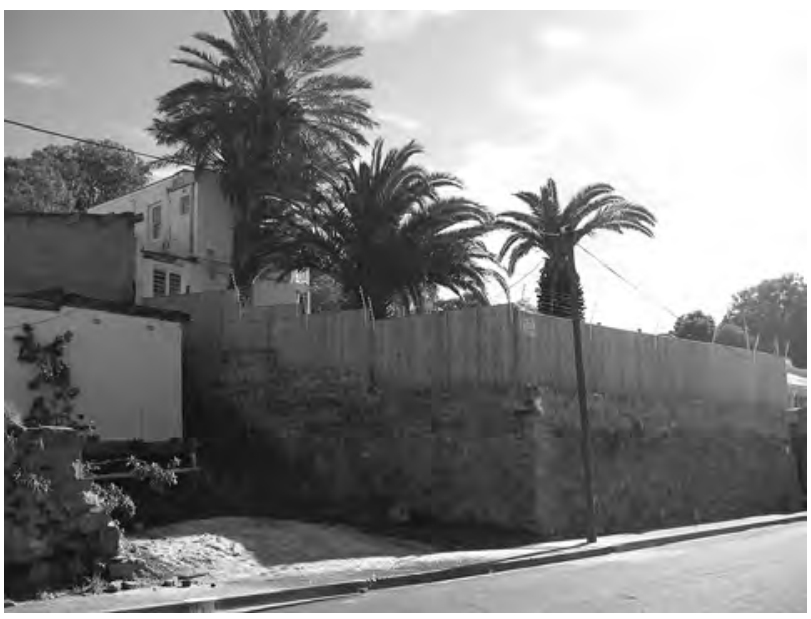

Figure 5: The most expensive housing unit sold in the Bo-Kaap during 2011 (being totally redeveloped; photo: Nico Kotze).

who used the same variables and questionnaire as that used in Nico Kotze's (1998) study to gauge population change in the neighbourhood. From this, it is clear that the replacement component of the older gentrification definition is not applicable to the Bo-Kaap area. 
Table 2: Changes in property sold and prices (1981-2011).

\begin{tabular}{|c|c|c|c|c|}
\hline Property features & 1981 & 1991 & 2001 & 2011 \\
\hline Number of housing units sold & 6 & 16 & 15 & 22 \\
\hline Lowest price obtained & 85,000 & 1,000 & 37,500 & 700,000 \\
\hline Highest price obtained (ZAR) & 27,500 & 145,000 & 650,000 & $2,650,000$ \\
\hline Average price of properties sold (ZAR) & 19,667 & 46,181 & 282,633 & $1,292,387$ \\
\hline Smallest parcel (plot) sold $\left(\mathrm{m}^{2}\right)$ & 109 & 48 & 69 & 61 \\
\hline Largest parcel sold $\left(\mathrm{m}^{2}\right)$ & 342 & 376 & 627 & 527 \\
\hline Average size of parcels sold $\left(\mathrm{m}^{2}\right)$ & 164 & 128 & 253 & 159 \\
\hline Number of mortgages registered (only 2011) & & & & $7^{*}$ \\
\hline Smallest mortgage registered (only 2011) (ZAR) & & & & 6,278 \\
\hline Largest mortgage registered (only 2011) (ZAR) & & & & 900,00 \\
\hline Average mortgage size registered (2011) (ZAR) & & & & $213,880^{* *}$ \\
\hline
\end{tabular}

Notes: $\left(^{*}\right)$ One of the previous owners is the mortgage holder; $\left(^{* *}\right)$ The average calculated from only six properties (one mortgage amount was not given).

Source: Adapted from Ronnie Donaldson et al. (2013).

\section{Characteristics of the property market in the Bo-Kaap}

A careful examination of the properties in the study area shows that enormous changes have taken place over time. The housing units have been upgraded (see Figures 3 and 4, where no evidence of a slum area can be observed) and the property values have increased dramatically (Table 2). The values of the housing units are influenced by their attributes, such as size, facilities, configuration, physical condition, accessibility and the surroundings of the unit. Furthermore, it was found in other studies that the neighbourhood in which a property is located certainly does have a significant impact on the value of the housing unit (Kain \& Quigley, 1970; Boyle \& Kiel, 2001; Din et al., 2001; Yau, 2011; Zhang et al., 2012). From Table 2, the increase in the property values of the area is clearly noticeable over a period of thirty years: from an average price of under ZAR 20,000 in 1981 to well over ZAR 1,000,000 (approximately EUR 120,000) in 2011. To put the average property price of 1981 into perspective: a newly built, three-bedroom, two-bathroom house could have been developed in the northern suburbs of Cape Town for ZAR 35,000 during this period. The numbers of properties that have changed ownership is still relatively low, but there has recently been an increase. In the past, very few properties were advertised on the property market, in a deliberate attempt by the inhabitants to protect the Islamic character of the area. Instead, news of those properties available for sale was spread by word-of-mouth to friends and relatives (Kotze, 1998).

Unfortunately, the size of the improvements (i.e., the size of the housing unit) on each plot of land was not stipulated in the data set that is available from the Cape Town Municipality; only the size of the land was made known. From Table 2, it is clear that the plots are very small by South African standards. In more affluent neighbourhoods of South African cities, plot sizes range from $1,000 \mathrm{~m}^{2}$ and larger; even houses provided by the South African government for the homeless are on plots of $250 \mathrm{~m}^{2}$ (see Moolla et al., 2011). Most of the houses in the neighbourhood are row units or semi-detached units, and in many cases the housing units have very small gardens or none at all.

A good example of the smallest property that was sold in 2011 also proved to be the cheapest property sold in that year (Figure 4). This property completely occupies the entire area of the plot, the terrace even extending right onto the curb of the road. This unit, on the corner of Chippinni Street and Church Street, is attached on two sides to other properties with the effect that windows on these sides of the property are disallowed. Only a door and two windows feature on its façade. The most expensive property sold in 2011 also occupies the largest plot. During the period from 2011 to 2012, this two-storey property was totally redeveloped by the new owner (see Figure 5). The second advantage associated with this property is that it is located on the crest of a hill in an area with very good views from most sides of the house of Table Mountain, the harbour and the CBD of Cape Town.

From discussions with inhabitants of the Bo-Kaap, it became clear that a large percentage of the housing units are occupied by two or more generations. To ascertain whether the community is in trouble on account of gentrification having taken place in the neighbourhood is difficult to answer. The value of properties in this suburb has increased dramatically, with the result that such properties are placed beyond the economic reach of some of the inhabitants. However, if records showing the application and allocation of mortgages to finance the twenty-two properties sold during 2011 are scrutinised, it is 
clear from the records of the Deeds Office in Cape Town that only seven (31.8\%) of the new owners registered mortgages. One of these deeds does not disclose the amount of the mortgage, but it is indicated in the records at the Deeds Offices that the mortgage-holder is the previous owner, a female, who bought the property in 1991. There are thus two possible scenarios: she married and the husband took over the property, or it was transferred to a sibling. The latter seems unlikely because the new owner has a different surname.

If the average property price (ZAR $1,292,387$ ) is compared to the average mortgage size (ZAR 213,880) in 2011 or the lack thereof, it seems that the community of the Bo-Kaap is not really that impoverished when it comes to property ownership. What could become a problem in the future would be the demise of a homeowner upon which all the siblings would demand their rightful share of the price that the property could fetch on the open property market. This could lead to the possibility that the units could be sold to outsiders and even euro-earning people from abroad.

\section{Conclusion}

Since the 2000s, there has been a significant shift away from inner-city decline in Cape Town, a trend that is not as clearly noticeable in the other major cities of South Africa. In the case of Cape Town, this has been promoted by programmes such as the City-Centre Improvement District (CCID) and major infrastructure investments, including transport, conference facilities, new hotels, office conversions and the developments at the Victoria and Albert Waterfront and Marina that have evidently reversed the trend of decay in the city. The turnaround strategy was facilitated by the development framework of the national and local governments, which played a significant role in the redevelopment of the CBD of Cape Town (see Visser \& Kotze, 2008). All of these developments have also had an impact on the Bo-Kaap, with old industrial buildings being converted into loft apartments and even the construction of a new Hilton Hotel (a huge bone of contention among some of the residents) within the boundaries of this neighbourhood.

Unfortunately, this storyline does not validate the displacement idea, which has tended to dominate the standard understanding of gentrification. What is clear from this narrative is that a vast number of changes have taken place in the Bo-Kaap over a number of decades. It has changed from a rundown neighbourhood, with buildings on the brink of being demolished in the 1930s, to a trendy, sought-after area with lots of appeal for visitors to Cape Town (the Mother City of South Africa). All these changes must have had a negative impact upon the older generation still residing in the area, who would desperately like to preserve the old "Cape Malay
Muslim" character of the area. It is the author's contention that, as property prices keep on rising and the older generation dies out, more housing units will fall into the hands of outsiders - and this very charming neighbourhood will lose its most distinctive characteristic landmarks. However, this is pure speculation and, listening to the fears and attitudes of the inhabitants, one is left with a strong sense that this group will do everything in its power to keep its neighbourhood and cultural heritage intact.

\section{Nico Kotze}

University of Johannesburg, Department of Geography, Environmental Management and Energy Studies, Johannesburg, South Africa

E-mail: nicok@uj.ac.za

\section{References}

Atkinson, R. (2000) The hidden cost of gentrification: Displacement in central London. Journal of Housing and the Built Environment, 15(4), pp. 307-326. DOI: 10.1023/A:1010128901782

Atkinson, R. (2004) The evidence of the impact of gentrification: New lessons for the urban renaissance? European Journal of Housing Policy, 4(1), pp. 107-131. DOI: 10.1080/1461671042000215479

Atkinson, R. \& Bridge, G. (eds.) (2005) Gentrification in a global context: The new urban colonialism. London, Routledge. DOI: $10.4324 / 9780203392089$

Beauregard, R. A. (1986) The chaos and complexity of gentrification. In: Smith, N. \& Williams, P. (eds.) Gentrification of the city. Boston, Allen \& Unwin.

Blomley, N. (2004) Unsettling the city: Urban land and the politics of property. New York, Routledge.

Bourne, L. S. (1993) The demise of gentrification? A commentary and prospective view. Urban Geography, 14(1), pp. 95-107. DOI: 10.2747/0272-3638.14.1.95

Boyle, M. A. \& Kiel, K. A. (2001) A survey of house price hedonic studies of the impact of environmental externalities. Journal of Real Estate Literature, 9(2), pp. 117-144.

Butler, T. \& Lees, L. (2006) Super-gentrification in Barnsbury, London: Globalization and gentrifying global elites at the neighbourhood level. Transactions of the Institute of British Geographers, 31(4), pp. 1-21. DOI: 10.1111/j.1475-5661.2006.00220.x

Cameron, S. (1992) Housing, gentrification and urban regeneration policies. Urban Studies, 29(1), pp. 3-14. DOI: 10.1080/00420989220080011

Cameron, S. (2003) Gentrification, housing redifferentiation and urban regeneration: "Going for growth" in Newcastle-upon-Tyne. Urban Studies, 40(12), pp. 2367-2382. DOI: 10.1080/0042098032000136110

Cape Archives, file 3/CT 4/2/1/1/720. Cape Town.

Cape Archives, file 3/CT 4/2/1/1/720 20/6/46. Cape Town.

Davids, A. (1990) Words the Cape slaves made: A socio-historical-linguistic study. South African Journal of Linguistics, 8(1), pp. 1-24. DOI: 10.1080/10118063.1990.9723811

Din, A., Hoesli, M. \& Bender, A. (2001) Environmental variables and real estate prices. Urban Studies, 38(11), pp. 1989-2000. DOI: 10.1080/00420980120080899

Donaldson, R., Kotze, N., Visser, G., Park, J. Wally, N., Zen, J. \& Vieyra, O. (2013) An uneasy match: Neoliberalism, gentrification and heritage 
conservation in Bo-Kaap, Cape Town, South Africa. Urban Forum, 24(2), pp. 173-188. DOI: 10.1007/s12132-012-9182-9

Du Plessis, I. D. \& Lückoff, C. (1953) The Malay Quarter and its people. Cape Town, Balkema.

Fillion, P. (1991) The gentrification - social structure dialectic: A Toronto case study. International Journal of Urban and Regional Research, 15(4), pp. 553-574. DOI: 10.1111/j.1468-2427.1991.tb00658.x

Franzén, M. (2005) New social movements and gentrification in Hamburg and Stockholm: A comparative study. Journal of Housing and the Built Environment, 20(1), pp. 51-77. DOI: 10.1007/s10901-005-6764-z

Glass, R. (1964) London: Aspects of change. London, MacGibbon \& Kee.

Hamnett, C. (1991) The blind men and the elephant: The explanation of gentrification. Transactions, Institute of British Geographers, 16(2), pp. 173-189. DOI: $10.2307 / 622612$

Harris, A. (2008) From London to Mumbai and back again: Gentrification and public policy in comparative perspective. Urban Studies. 45(12), pp. 2407-2428. DOI: 10.1177/0042098008097100

Jeppe, S. (1986) Historical process and the constitution of subjects. Cape Town, University of Cape Town.

Kain, J. F. \& Quigley, J. M. (1970) Measuring the value of housing quality. Journal of the American Statistical Association, 65(330), pp. 532-548. DOI: $10.2307 / 3384565$

Kotze, N. (1998) Gentrifikasie as Stedelik Geografiese verskynsel in Kaapstad [Gentrification as an urban geographical phenomenon in Cape Town]. Doctoral thesis, Stellenbosch, University of Stellenbosch.

Kotze, N. \& Van der Merwe, I. J. (2000) Neighbourhood renewal in Cape Town's inner city: Is it gentrification? Journal of Family Ecology and Consumer Sciences, 28, pp. 39-46.

Lees, L. (1994) Gentrification in London and New York: An Atlantic gap? Housing Studies, 9(2), pp. 199-217. DOI: 10.1080/02673039408720783

Lees, L. (2008) Gentrification and social mixing: Towards an inclusive urban renaissance. Urban Studies, 45(12), pp. 2449-2470. DOI: $10.1177 / 0042098008097099$

Lees, L., Slater, T. \& Wyly, E, (2008) Gentrification. New York, Routledge.

Ley, D. (1994) Gentrification and the politics of the new middle class. Environment and Planning D, 12(1), pp. 53-74. DOI: 10.1068/d120053

Márquez, F. (2011) Santiago: Modernisation, segregation and urban identities in the twenty-first century. Urbani izziv, 22(2), 86-97. DOI: 10.5379/urban-izziv-en-2011-22-02-002

Moolla, R., Kotze, N. \& Block, L. (2011) Housing satisfaction and quality of life in RDP houses in Braamfischerville, Soweto: A South African case study. Urbani izziv, 22(1), pp. 138-143.

DOI: 10.5379/urbani-izziv-en-2011-22-01-005

Murphy, L. (2008) Third-wave gentrification in New Zealand: The case of Auckland. Urban Studies, 45(12), pp. 2521-2540. DOI: $10.1177 / 0042098008097106$

Rofe, M. W. (2003) 'I want to be global': Theorising the gentrifying class as an emergent elite global community. Urban Studies, 40(12), pp. 2511-2526. DOI: 10.1080/0042098032000136183

Smith, D. (2008) The politics of studentification and "(un)balance" urban populations: Lessons for gentrification and sustainable communities? Urban Studies, 45(12), pp. 2541-2564. DOI: 10.1177/0042098008097108

Smith, N. (1979) Towards a theory of gentrification: A back-to-the-city movement of capital, not people. Journal of the American Planning Association, 45(4), pp. 583-548. DOl: 10.1080/01944367908977002
Smith, N. (2002) New globalism, new urbanism: gentrification as a global urban strategy. Atipode, 34(3), pp. 427-450. DOI: 10.1111/1467-8330.00249

Smith, N. \& Williams, P. (eds.) (1986) Gentrification of the city, London, Unwin Hyman.

Statistics South Africa (1996) 1996 census. Pretoria.

Statistics South Africa (2001) 2001 census. Pretoria.

Statistics South Africa (2011) 2011 census. Pretoria.

Todeschini, F. \& Japha, D. (2003) Cultural identity and architectural image in Bo-Kaap. In: AlSayyad, N. (ed.) The end of tradition? pp. 187-208. London, Routledge.

Visser, G. \& Kotze, N. (2008) The state and new-built gentrification in central Cape Town. Urban Studies, 45(12), pp. 2565-2593. DOI: $10.1177 / 0042098008097104$

Wilkinson, R. \& Kragolsen-Kille, A. (2006) Bo-Kaap: Inside Cape Town's Malay quarter. Cape Town, Struik.

Yau, Y. (2011) Does comprehensive redevelopment change the housing price gradient? A case study in Mongkok, Hong Kong. Urbani izziv, 22(2), pp. 98-106. DOI: 10.5379/urban-izziv-en-2011-22-02-003

Zhang, J., Kotze, N. \& Yu, M. (2012) Living in a changing Chinese urban landscape: The Dalian case study. Urbani izziv, 23(2), pp. 93-102. DOI: 10.5379/urban-izziv-en-2012-23-02-002 